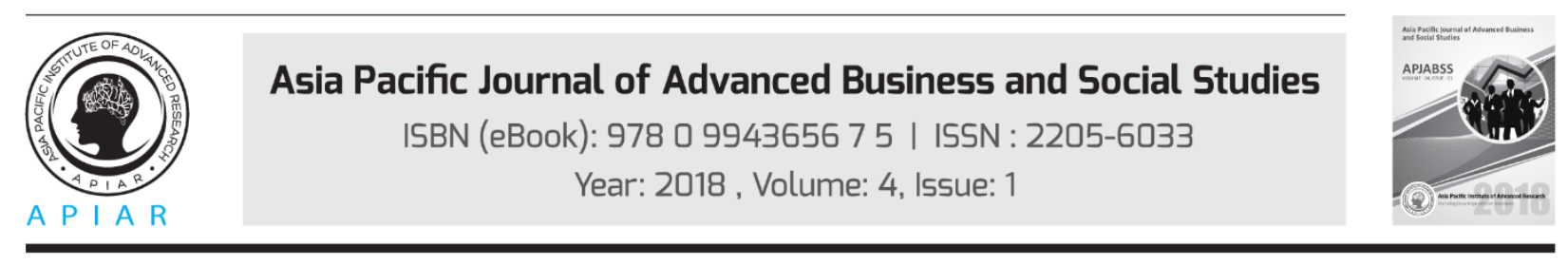

\title{
TRYING TO BUY A NEW PRODUCT: WHAT DOES ADVERTISING DO NOWADAYS?
}

\author{
Cynthia Ayu Manggarani ${ }^{\mathrm{a}}$,Basu Swastha Dharmmesta ${ }^{\mathrm{b}}$ \\ ab Universitas Gadjah Mada, Yogyakarta, Indonesia \\ Corresponding email: cynthia.mrsc@gmail.com
}

\begin{abstract}
This research is conducted based on marketer's concern about whether new products offered by a company would be acceptable by its existing customers or not. These concerns arise since generally consumers tend to doubt the quality of a new product which is not obvious. Despite the overabundant and saturating advertising in todays' market, this research tries to prove that advertising is still considered effective in strengthening consumers' intention to try a new product offered by a particular company. The most popular skin clinic in Indonesia named Natasha Skin Care was chosen to be the object of this research. The topic in this research is then discussed based on Theory of Trying developed by Bagozzi and Warshaw (1990), a theory that is still quite under-researched compared to the previous theory explaining human actions such as Theory of Planned Behavior. By using the theory, consumer's motivation to achieve a specific goal will be tested simultaneously with attitude towards advertising in order to see their effects on attitude towards trying and their intention to buy the new products.Samples are 614 customers of Natasha Skin Care who have been using Natasha products, other than the new hair products, for at least 6 months. Results show that customers would have the intention to buy the new product if only they have a strong motivation to achieve a particular goal, in this case, try to get a good hair. In fact, advertising also becomes an important determinant to strengthen consumers' attitude toward trying a new product offered by the company, and also strengthening their intention to try. Recommendations from the study are that the content of advertising should be emphasized on elevating consumers' willingness to achieve a particular goal, and encouraging the consumers to think that the goal would be crucial for them in the future.
\end{abstract}

Keywords: Theory of Trying, Advertising, Intention, New Product.

\section{Introduction and Purpose}

A number of researchers have focused on investigating the determinants of new product acceptance (e.g., Yeniyurt and Townsend, 2003; Yao et al 2009; Beck and Kenning, 2015). Most of them prefer to emphasize on the characteristics possessed by the product being offered rather than on factors that may come from the potential buyers, such as their motivation to buy.Moreover, despite many findings, there is only onethat examined the actual factors of new product acceptance, which is the motivation to achieve a particular goal from the customer itself.

However, a person's motivation toward something new does not appear by itself, especially when the act of trying is related to something that is not certain. To build his attitude, a person 
should be able to access his cognitive or affective evaluation towards a specific behavior or object (Schifmann and Kanuk, 2010). Unfortunately, someone's cognitive capacity is limited when he has no clue about the future events (Fazio, 2007), which in this case, is the trying act.

One alternative that can be proposed to enhance a person's cognitive and affective evaluation is throughconditioning (Hofmann et al 2010). Advertising, in many of its forms, is believed as an effective medium to deliver the message from producer to consumer (e.g. Stuart et al 1987; Baker, 1999; Vermeulen and Beukeboom, 2016). If the consumers like what they see in an advertisement in a search of a brand, then they will make sure to search that brand (Nelson, 1970). This isone of the reasons why a positive attitude towards advertising can also increase consumer's tendency to form their intention to buy a product from particular brand (e.g., Lutz et al 1983; MacKenzie et al 1986; Mitchell and Olson 1981; Shimp, 1981).

In practice, theconcerns among the marketers regarding the acceptability of new products that they are going to offer to the customers are real (e.g. Ottman, 1998; Shaw et al 2004; Stock and Balachander, 2005). These concerns arise since new products may possibly fail to achieve the expected market acceptance because customers find it difficult to accept a product with unknown quality (Yao et al 2009). In fact, there is a persistent perception in product innovation and management that the failure rate of new products is $80 \%$ or even higher (Castellion and Markham, 2013).

One of the many industries facing the rapid pace of new product demand is the pharmaceutical industry. The Pharmaceutical industry places a heavy emphasis on research and development compared with other industrial sectors. Companies within this industry are expected to achieve maximum market penetration in a limited time frame since they have to pace with narrow period of patent (Matikainen et al 2015). Therefore, it is quite likely that any company in pharmaceutical industries would compete to produce new products in order not to be beaten by their competitors.

Serving in the pharmaceutical industry,hair care products firms have undergone a revolutionary change over the last two decades (Madnani and Khan, 2013). The focus has dramatically veered from merely cleaning to repair, increasing the tensile strength, reducing oxidative damage, and stimulating growth (Madnani and Khan, 2013). In the United States, the sales growth of hair care products is increasing rapidly (MMR New York, N.Y., 2017). In Indonesia, although there is only little public data showing the sales growth of hair products in Indonesia, data provided by Indonesian Republic Ministry in 2013 showed thatthere has been a significant increase in cosmetics sales in Indonesia since 2012 (website of Indonesian Republic Ministry of Industry, 2016). It indeed, shows the high demand of cosmetics products in the country.

Furthermore, manufacturers continued to introduce new products to address specific Indonesian consumer needs in 2013 (CompaniesandMarkets.com). The data showsthat with the urbanisation and increasingly busy lifestyle of Indonesia urban consumers, they have less time to have hair treatment at a beauty salon (CompaniesandMarkets.com).Companies; therefore, introduced professional hair care products to retail during 2013, targeting at the middleto upper-income consumers (CompaniesandMarkets.com).

In order to capture the promising market, Natasha Skincare, as a most trusted brand in Indonesia skin care industry (Topbrand, 2016), expands the market into hair care products. By doing this, the problem of new product acceptance will be faced by its marketers. Therefore, to cope with the recent solve problem, this research examined the effect of consumer's attitude towards advertising on one's attitude towards trying and one's intention to try new product based on Theory of Trying (Bagozzi and Warshaw, 1990). At the same time, the model in this researchcan be the resource of explanation regarding whether or not motivation of the person itself has something to do with his willingness to try the new product offered by a company. 


\section{The Literature Review}

Information about quality differs from information about price, because information about quality is usually more expensive to buy than the information about price (Nelson, 1970). One can, for example, readily determine the price of a body lotion, however it is way more difficult to determine the performance of a body lotion when further information is poor.

The same thing happens when one has to decide whether or not to try the new product offered by a particular company. When it comes to a new product with unknown quality, consumers need more information to sense that unknown quality in order to decide to try the new product (Yao et al 2009). This is especially applied when the decision to try involves a risky product.

Basically, people form beliefs about what they can do, they anticipate the likely consequences of prospective actions, they set goals for themselves, and they otherwise plan courses of action that are likely to produce desired outcomes (Bandura, 1991). Ultimately, people's beliefs in their efficacy will influence the choices they make (Bandura, 1991), whether or not they dare to try, is indeed based on their efficacy.

Yet, when behaviors are not well learned or when they are performed in difficult contexts, conscious decision making is likely to be necessary to initiate (Oulette and Wood, 1988).Even when a person already has a motivation to generate a specific act, a series of future consequences may affect their assesment towards the act itself. Past behaviour serves as a type of informational input to the decision to act, in addition to attitudes and subjective norms (Bagozzi and Kimmel, 1995). Frequency of past behavior, in point of fact, hasa direct effect on future performance (Oulette and Wood, 1988). The success of achieving a particular goal in the past can significantly lead to future behavior for similar actions (Oulette and Wood, 1988). Therefore, we believe that it is useful to consider the role of past behavior to iniate customers intention to try a new product offered by a company.

At last, in forming their intention to buy something new with unknown quality, one would need an opinion about what important others think he should do (Finlay et al 1997). Perception of the attitudes of significant others influencesone's attitude which, in turn, influences intentions (Greene et al 1997). This makes the sense that one would need a suggestion from others in order to avoid the bad consequences that might happen from making a bad decision.

\section{Theory of Trying}

Theory of trying is designed to explain strivings to perform a behavior or achieve a goal (Bagozzi and Kimmel, 1995). When one tries to achieve a problematic and or perform a difficult behavior, a triad of concerns becomes salient: trying and succeeding, trying but failing, and the process of striving (Bagozzi and Kimmel, 1995). When one tries to achieve a goal, they see it as a potential burden that only has one consequences which is succeeding, since they think any consequences related to the act of trying is important for them (Dharmmesta, 2000).

Theory of Trying (Bagozzi and Warshaw, 1990) treats attitude as having multi dimensions which are divided into three components: attitudes toward success, attitudes to failure, and attitudes toward the process. Bagozzi and Warshaw (1990) argued, that dividing attitudes into three different components will better to explain the influence of individual motive on intention. Moreover, attitudes only provide a measure of one's involvement effectively with a behavior,therefore the motivation to act for a person depends on his willingness to carry out the behavior (Dharmmesta, 2002). This explains that by treating attitude as a unidimension will indirectly override the influence of individual motive on intentions (Dharmmesta, 2000). 
Several empirical researches have provided suportive evidences for the use of Theory of Trying in the prediction of various behaviors (e.g., Dharmmesta, 2002; Thatcher and Ahuja, 2005; Thesiana, 2006). On the contrary, several researchers prefer to treat attitude as a unidimension concept (Curran and Meuter, 2005; Jones et al 2015; Kaushik and Rahman, 2015). However, the numbers of research based in this theory is still limited compared to TRA and TPB (Chaouali et al 2017). Hence, a more empirical research using this theory need to be conducted in order to examine the predictive power of Theory of Trying.

\section{Advertising}

Advertisement is one of marketing tools that is favorable for marketers since its ability to create brand equity (Wang et al 2009). Brand equity itself is a consumer perception about the product quality and it can also simultaneously form consumer intention to buy (Brady et al 2008). Advertising is also believed to increase buyers' response rate towards products offered by a particular company and reminds the consumer about its advantages (Eze and Lee, 2012). Consumers form their affective and cognitive aspects as a result of advertising exposure (Schiffman and Kanuk, 2010, pp. 256). These aspects will then affect attitude towards advertising and brand trust as a consequence of advertising exposure.

After all, even advertising experts have paid a huge attention on attitude towards advertising variable as an affective construct which has a significant effect on people intention to buy (e.g., Lutz et al 1983; MacKenzie et al 1986; Mitchell and Olson, 1981; Shimp, 1981) and also the fact that attitude towards advertising was proven to have a direct effect on consumer's intention to buy (Gresham and Shimp, 1985), yet recent literatures provided contra evidences. Duff and Faber (2011) stated that people avoid stimuli of advertising while engaged in a search or focused activity. Aydogdu and Wellman (2011) even stated that in an information search of risky products, advertising is no guarantee of success.Companies that advertise will do no better at generating new sales when compared to companies that do not advertise at all (Aydogdu and Wellman, 2011).

\section{The effect of attitude towards advertising on attitude towards trying}

Attitudes toward a specific behavior refer to personal evaluations being favorable or unfavorable to perform the behavior (Schifter \& Ajzen, 1985).According to Fishbein and Ajzen's (1975) expectancy value model, attitudes develop from the beliefs people hold about the objects of the attitude. Beliefs about an object is formed by associating it with certain attributes (Ajzen, 1991). In the case of attitudes toward a behavior, each belief links the behavior to a certain outcome, or to some other attribute such as the cost incurred by performing the behavior (Ajzen, 1991). Since the attributes that come to be linked to the behavior are already valued positively or negatively, we automatically and simultaneously acquire an attitude toward the behaviour (Ajzen, 1991).

Several studies proved that attitude towards object positively affect attitude towards behavior (e.g., Rosenberg, 1956: Friestad and Wright, 1994; Stedman, 2002). As stated by Ajzen (1991), one's attitude towards a particular object can mediate himself into the formation of his attitude towards behavior when the future behavior is not certain. Accordingly, attitude towards advertising can influence one's attitude towards trying to buy something new offered by a company.

\section{The effect of attitude towards success, failure, and process on attitude towards trying}

Succeeding and failing clearly refer to end-state outcomes, while the process refers to the consequences enroute to the end state (Bagozzi and Kimmel, 1995). As stated by Dharmmesta (2000), the only consequence of strivings to achieve a goal is succeeding. Success in goal attainments builds a sense of personal efficacy (Bandura, 1991). High achievers tend to invest their self-satisfaction in attainment of challenging goals, while low achievers adopt easy goals as 
sufficing (Bandura, 1991). One's evaluation towards failure which is mostly perceived as negative in several literatures (e.g., Xie et al 2008; Chaouali et al 2017), is hence perceived to be positive in this research. Thus, the higher the aspirational standards people set for themselves, the more likely their evaluation towards failure is positive. These variables in turn, will affect attitude toward trying in positive direction.

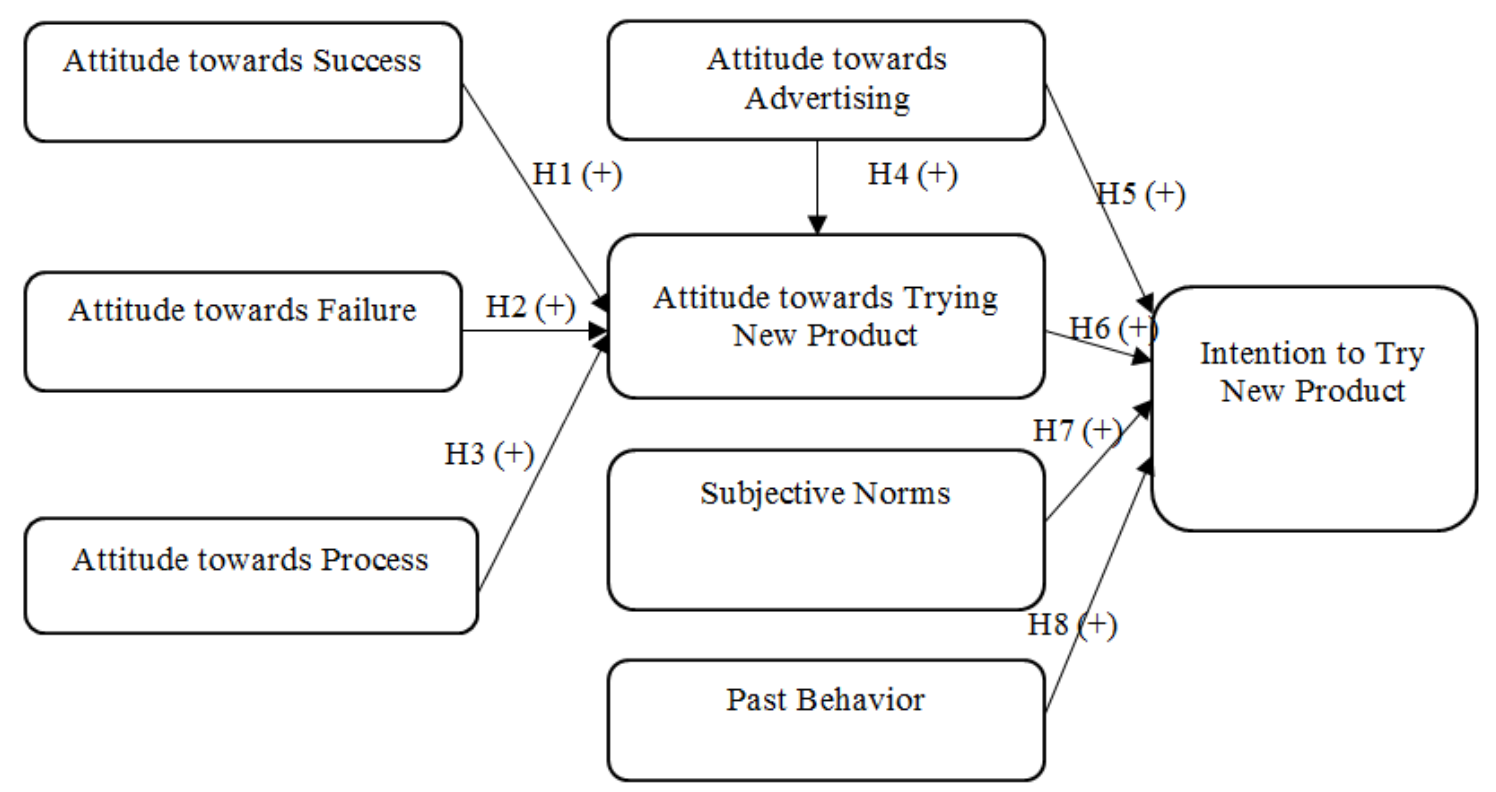

Figure 1. Proposed research model.

Based on the literature explained beforehand, eight hypotheses were generated and thus proposed in this research.

H1: Attitude towards success has a positive effect on attitude towards trying a new product offered by a company.

H2: Attitude towards failure has a positive effect on attitude towards trying a new product offered by a company.

H3: Attitude towards process has a positive effect on attitude towards trying a new product offered by a company.

H4: Attitude towards advertising has a positive effect on attitude towards trying a new product offered by a company.

$\mathrm{H}_{5}$ : Attitude towards advertising has a positive effect on attitude towards trying a new product offered by a company.

H6: Attitude towards trying a new product has a positive effect on intention to try a new product offered by a company.

H7: Subjective norms has a positive effect on intention to try a new product offered by a company.

H8: Past behavior has a positive effect on intention to try a new product offered by a company.

\section{Methodology}

The data collection in this research was conducted in two stages. The first stage was conducted through qualitative and the second stage was through quantitative method. In the first stage, an elicitation study on a representative sample of the population was conducted as a standard 
procedures developed for identifying modal salient attributes or outcomes associated with an attitude objects or behavior (Fishbein and Middlestadt, 1995).

In the first stage, interviewswereconducted with 30Natasha Skincare customers to collect their salient modal beliefs about trying to buy the new hair products offered by Natasha skin care. The criteria of the informant in this first stage are as follow: (1) they have been using Natasha Skincare products, other than the new hair products, for at least six months; (2) they have seen Natasha Skincare advertising of the new hair products; and (3) theminimum age of the participant is 18 years old.

After the interview, the transcript of the conversation were analyzed using content analysis. A content analysis and calculation of the open-ended responses allow one to identify the attributes or outcomes set (Patiro et al 2016). The set is thus comprised of those attributes or outcomes that are mentioned most frequently by the population being considered (Patiro et al 2016). One rule of thumb is to include all attributes or outcomes mentioned by at least ten percent of the sample (Patiro et al 2016). Those attributes or outcomes that are elicited most frequently are included in the modal set and are used as the basis for quantitative measures in the questionnaire.

The second stage is the administration of quantitative method which is aimed to examine the effect of Theory of Trying variables (attitude, subjective norms, past behavior) on consumer intention to buy the new products offered by Natasha Skincare, and also the effect of attitude toward advertising on attitude toward trying to buy a new product as well as its effect on consumer's intention to buy the new product. In this stage, questionnaires were distributed to the respondents with the predetermined categories stated before. Data collection were conducted in three stores of Natasha Skincare and the sample size of this research is 614 (see Hair et al 2014, pp. 574; Anderson and Gerbing, 1988).

Furthermore, construct validity test consists of convergence and discriminant validity was conducted. After the result of construct validity test was obtained and was in accordance as expected, Structural Equation Modelling (SEM) method wasapplied to examine the effect of Theory of Trying variables and the added variable (attitude toward advertising) on consumer's intention to try the new hair products.SEM analysis was used to evaluate the structural or path model. Additionally, SEM can examine a series of dependence relationships simultaneously (Hair et al 2014, pp. 542). It is particularly useful in testing theories that contain multiple equations involving dependence relationships (Hair et al 2014, pp. 542). To do the analysis, AMOS 4 software was utilized in this study.

\section{Results}

Results show that among all paths, only one is below 0.05 level, which is the effect of attitude towards failure on attitude towards trying to buy the new product. To assess the fit of the model, an examination of the fit indices is required (Hair et al 2014). Comparative Fit Index (CFI): values larger than 0.90 indicate good fit - Normed Fit Index (IFI),): values larger than 0.90 indicate good fit - Goodness of Fit Index (GFI) and Adjusted Goodness of Fit Index (AGFI): values larger than 0.90 indicate good fit, and - Root Mean Square Error of Approximation (RMSEA): values between 0.05 and 0.08 indicate good fit (Hair et al 2014). Accordingly, based on the goodness of fit model testing in this research, the following results were obtained: $\mathrm{CMIN} / \mathrm{DF}=4.934 ; \mathrm{RMSEA}=0.081 ; \mathrm{GFI}=0.989 ; \mathrm{AGFI}=0.942 ; \mathrm{CFI}=0.944$.

Coefficient path analysis is purposed to test the hypotheses in this research. The significancy of effect can be seen from the critical ratio which is greater than $\pm 1,96$ on 0,05 significancy level or greater than $\pm 2,58$ on 0,01 significancy level. Table 10 showed that from the eight hypotheses 
proposed, one of them, which is the hypothesis regarding the effect of attitude towards failure on attitude towards trying is not supported.

Table 1: Hypotheses testing

\begin{tabular}{|l|c|c|}
\hline \multicolumn{1}{|c|}{ Hypotheses } & $\begin{array}{c}\text { Critical } \\
\text { Ratio = t }\end{array}$ & Decision \\
\hline $\begin{array}{l}\text { H1: Attitude towards success is having a } \\
\text { positive effect on attitude towards trying a new } \\
\text { product. }\end{array}$ & 4,170 & Supported \\
\hline $\begin{array}{l}\text { H2: Attitude towards failure is having a positive } \\
\text { effect on attitude towards trying a new product. }\end{array}$ & 1,252 & $\begin{array}{c}\text { Not } \\
\text { Supported }\end{array}$ \\
\hline $\begin{array}{l}\text { H3: Attitude towards process is having a } \\
\text { positive effect on attitude towards trying a new } \\
\text { product. }\end{array}$ & 2,517 & Supported \\
\hline $\begin{array}{l}\text { H4: Attitude towards advertising is having a } \\
\text { positive effect on attitude towards trying a new } \\
\text { product. }\end{array}$ & 2,554 & Supported \\
\hline $\begin{array}{l}\text { H5: Attitude towards advertising is having a } \\
\text { positive effect on intention to try a new product. }\end{array}$ & 2,570 & Supported \\
\hline $\begin{array}{l}\text { H6: Attitude towards trying is having a positive } \\
\text { effect on intention to try a new product. }\end{array}$ & 3,792 & Supported \\
\hline $\begin{array}{l}\text { H7: Subjective norms is having a positive effect } \\
\text { on intention to try a new product. }\end{array}$ & 3,593 & Supported \\
\hline $\begin{array}{l}\text { H8: Past behavior is having a positive effect on } \\
\text { intention to try a new product. }\end{array}$ & 4,423 & Supported \\
\hline
\end{tabular}

\section{Conclusion}

This research is conducted to examine the degree of consumer's courage to try the new product offered by a company. The main reason for this research to be conducted under this particular topic is the customers low response regardingnew product acceptance (Castellion and Markham, 2013).Hair care products became the object of this research since recently,among all cosmetics products, its existence is considered as having a huge potential market.An affective construct named attitude towards advertising was thus proposed as a complement of Theory of Trying (Bagozzi and Warshaw, 1990) to better explain consumer's willingness towards trying the new product offered by a company that they already recognized and trust.

Results show that all hypotheses are accepted, except one, which is the effect of attitude towards failure on attitude towards trying. The insignificant result of this hypothesis was perhaps caused by the difference of settings used between this research and those conducted previously. It might also be caused by the level of riskyness involved regarding the trying act, whichengenders customersdoubtnessto try because they are afraid with the consequences of failing. However, we can not assume those possibilities until further exploratory research is administered.

Ultimately, this research proves thatattitude towards the new hair product advertising is affirmed to has positive effect on attitude towards trying and also on consumer's intention to buy Natasha new hair care product. The results also support the ability power of affective component that is proposed in this research, to complement Theory of Trying in explaining the process of consumer's intention formation. 


\section{Managerial Implications}

This research has confirmed that attitude towards advertising has a positive and significant effect on attitude towards trying and intention to try new product. This implies that companies would benefit from considering these dimensions when constructing their advertising content. Based on the findings, a person will pretend that a trying behavior is worth it when one has a positive attitude towards success and process.

The fact from this research is that advertising generally present favorable information about the new featured products. When individuals have an adequate cognitive capacity to process the advertising message they will build their positive attitude towards advertising and further, increasing their attitude towards trying. The significant effect of attitude towards success on attitude towards trying also shows that to build one's positive attitude towards trying, it is expected for individuals to be motivated to engage in the trying act.Therefore, stakeholders should consider adapting the content of advertisement which will then persuade consumer's motivation to try. 


\section{References}

i. Ahuja, M.K. and Thatcher, J.B., 2005. Moving Beyond Intentions and toward the Theory of Trying: Effects of Work Environment and Gender on Post-adoption Information TechnologyUse. MIS Quarterly, 29(3), pp.427-459.

ii. Ajzen, I., 1991. The Theory of Planned Behavior. Organizational Behavior and Human Decision Process, 50, pp. 179-211.

iii. $\quad$ Anderson, J.C. and Gerbing, D.W., 1988. Structural Equation Modeling in Practice: A Review and RecommendedTwo-step Approach. Psychological Bulletin, 103(3), pp.411-423.

iv. Aydogdu, M. and Wellman, J.W., 2011. The Effects of Advertising on MutualFund Flows: Results from a NewDatabase. Financial Management, 4O(3), pp.785-809.

v. $\quad$ Bagozzi, R.P. and Kimmel, S.K., 1995. A Comparison of Leading Theories for the Prediction of Goaldirected Behaviors. British Journal of Social Psychology, 34, pp. 437-461.

vi. Bagozzi, R.P. and Warshaw, P.R., 1990. Trying to Consume.Journal of Consumer Research, 17, pp. 127-140.

vii. $\quad$ Baker, W.E., 1999. When Can Affective Conditioning and Mere Exposure Directly InfluenceBrand Choice?.Journal of Advertising, 28(4), pp.31-46.

viii. Bandura, A., 1991. Social Cognitive Theory of Self-regulation. Organizational Behavior and HumanDecisionProcesses, 5o(2), pp.248-287.

ix. Beck, S. and Kenning, P., 2015. The Influence of Retailers 'Family FirmImage on New Product Acceptance: An Empirical Investigation in the German FMCG Market. International Journal of Retail and Distribution Management, 43(12), pp.1126-1143.

x. Brady, M.K., Cronin, J.J., Fox, G.L. and Roehm, M.L., 2008. Strategies to Offset Performance Failures: The Role of Brand Equity.Journal of Retailing, 84(2), pp. 151-164.

xi. Castellion, G. and Markham, S.K., 2013. Perspective: New Product Failure Rates: Influence of Argumentum ad populum and Self-interest. Journal of Product Innovation Management, 30(5), pp.976-979.

xii. Chaouali, W., Souiden, N. and Ladhari, R., 2017. Explaining Adoption of Mobile Banking with the Theory of Trying, General Self-confidence, and Cynicism.Journal of Retailing and Consumer Services, 35, pp.57-67.

xiii. Curran, J.M. and Meuter, M.L., 2005. Self-service Technology Adoption: Comparing Three Technologies. Journal of ServicesMarketing, 19(2), pp.103-113.

xiv. Dharmmesta, B.S., 200o. Perilaku MencobaBeli: Sebuah Kajian Analitis Model BagozziWarshawuntuk PanduanPeneliti. Jurnal Ekonomidan Bisnis Indonesia, 15(4), pp.453-470.

xv. Dharmmesta, B.S., 2002. Trying to Act: An Empirical Study of Investigating Higher Education Consumers.GadjahMada International Journal of Business, 4(1), pp. 45-66.

xvi. $\quad$ Duff, B.R. and Faber, R.J., 2011. Missing the Mark. Journal of Advertising, 4O(2), pp.51-62.

xvii. $\quad$ Eze, U.C. and Lee, C.H., 2012. Consumers' Attitude towards Advertising. International Journal of Business and Management, 7(13), pp.94-108.

xviii. Fazio, R.H., 2007. Attitudes as Object-evaluation Associations of Varying Strength. Social Cognition, 25(5), pp.603-637.

xix. Finlay, K.A., Trafimow, D. and Jones, D., 1997. Predicting Health Behaviorsfrom Attitudes and Subjective Norms: Between-subjects and Within-subjects Analyses. Journal of Applied Social Psychology, 27(22), pp.2015-2031. 
xx. Fishbein, M. and Ajzen, I., 1975.Belief, Attitude, Intention and Behavior:An Introduction to Theory and Research. Reading, Massachusetts: Addison-Wesle.

xxi. Fishbein, M. and Middlestadt, S., 1995. NoncognitiveEffects on AttitudeFormation and Change: Fact or Artifact?. Journal of Consumer Psychology, 4(2), pp.181-202.

xxii. Friestad, M. and Wright, P., 1994. The PersuasionKnowledgeModel: How PeopleCope with Persuasion Attempts. Journal of Consumer Research, 21(1), pp.1-31.

xxiii. Greene, K., Hale, J.L. and Rubin, D.L., 1997. A Test of the Theory of Reasoned Action in the Context of CondomUse and AIDS. Communication Reports, 1O(1), pp.21-33.

xxiv. Gresham, L.G. and Shimp, T.A., 1985. Attitude toward the Advertisement and Brand Attitudes: A Classical Conditioning Perspective. Journal of Advertising, 14(1), pp.10-49.

xxv. $\quad$ Hair, J.F., Black, W.C., Babin, B.J. and Anderson, R.E., 2014.Multivariate Data Analysis, 7th ed. Upper Saddle River, New Jersey: Prentice-Hall Inc.

xxvi. Hofmann, W., De Houwer, J., Perugini, M., Baeyens, F. andCrombez, G., 2010. Evaluative Conditioning in Humans: AMeta-analysis. Psychological Bulletin, 136(3), pp.390-421.

xxvii. $\quad$ Jones, M.A., Reynolds, K.E., Arnold, M.J., Gabler, C.B., Gillison, S.T. and Landers, V.M., 2015. Exploring Consumers' Attitude towards Relationship Marketing. Journal of Services Marketing, 29(3), pp.188-199.

xxviii. Kaushik, A.K. and Rahman, Z., 2015. An Alternative Model of Self-service Retail Technology Adoption. Journal of Services Marketing, 29(5), pp.406-420.

xxix. Lutz, R.J., MacKenzie, S.B. and Belch, G.E., 1983.Attitude toward the Ad as a Mediator of Advertising Effectiveness: Determinants and Consequences.Advances in Consumer Research, 10, pp. 523-539.

xxx. MacKenzie, S.B., Lutz, R.J. and Belch, G.E., 1986. The Role of Attitude toward the Ad as a Mediator of Advertising Effectiveness: A Test of Competing Explanations .Journal of Marketing Research, 23, pp.130-143.

xxxi. Madnani, N. and Khan, K., 2013. Hair Cosmetics. Indian Journal of Dermatology, Venereology, and Leprology, 79(5), pp.654-667.

xxxii. Matikainen, M., Rajalahti, T., Peltoniemi, M., Parvinen, P. and Juppo, A., 2015. Determinants of New Product Launch Success in the Pharmaceutical Industry. Journal of Pharmaceutical Innovation, $10(2)$, pp.175-189.

xxxiii. Nelson, P., 1970.Information and Consumer Behavior. Journal of Political Economy, 78(2), pp. 311329.

xxxiv. Ouellette, J.A. and Wood, W., 1998. Habit and Intention in Everyday Life: The Multiple Processes by Which Past Behavior PredictsFutureBehavior. Psychological Bulletin, 124(1), pp.54-74.

xxxv. Patiro, S.P.S., Dharmmesta, B.S., Nugroho, S.S. and Sutikno, B., 2016. Extended Theoryof PlannedBehaviorasModelof Anabolic Androgenic Steroid Use by Indonesian Bodybuilders. Journal of Indonesian Economy and Business: JIEB, 31(1), p.102-106.

xxxvi. $\quad$ Rosenberg, M.J., 1956. Cognitive Structure and Attitudinal Affect. The Journal of Abnormal and SocialPsychology, 53(3), pp.367-372.

xxxvii. Schiffman, L.G. and Kanuk, L.L.,2010.Consumer Behavior, 10th ed. Upper Saddle River, New Jersey: Pearson Education/Prentice Hall.

Schifter, D.E. and Ajzen, I., 1985. Intention, PerceivedControl, and Weight Loss: An Application of the Theory of Planned Behavior. Journal of Personality and Social Psychology, 49(3), pp.843-851. 
xxxix. Shaw, C.T., Shaw, V. and Enke, M., 2004. Relationships between Engineers and Marketers within New Product Development: An Anglo-German Comparison. European Journal of Marketing, 38(5/6), pp.694-719.

xl. Shimp, T.A., 1981.Attitude toward the Ad as a Mediator of Consumer Brand Choice.Journal of Advertising, 10(2), pp.9-15.

xli. Stedman, R.C., 2002. Toward a Social Psychology of Place: Predicting Behavior from Place-based Cognitions, Attitude, and Identity. Environment and Behavior, 34(5), pp.561-581.

xlii. Stock, A. and Balachander, S., 2005. The Making of a "HotProduct": A SignalingExplanation of Marketers' ScarcityStrategy. Management Science, 51(8), pp.1181-1192.

xliii. Stuart, E.W., Shimp, T.A. and Engle, R.W., 1987. Classical Conditioning of ConsumerAttitudes: Four Experiments in an Advertising Context. Journal of Consumer Research, 14(3), pp.334-349.

xliv. Thesiana, K.C., 2006. AnalisisSikapdanNiatuntukMencobaterhadapPercobaanKonsumenMenggunakan Notebook Acer Travelmate 2428 ANWXCI di Fakultas Ekonomi Universitas Gadjah Mada: Sebuah Studi yang Menggunakan TeoriPerilaku Mencoba-Beli. Thesis of Master Management Universitas Gadjah Mada (not published).

xlv. Vermeulen, I. and Beukeboom, C.J., 2016. Effects of Music in Advertising: Three Experiments Replicating Single-exposure Musical Conditioning of Consumer Choice (Gorn 1982) in an Individual Setting. Journal of Advertising, 45(1), pp.53-61.

xlvi. Wang, C.H., Hsu, L.C. and Fang, S.R., 2009. Constructing a Relationship-based Brand EquityModel. Service Business, 3(3), pp.275-292.

xlvii. Xie, C., Bagozzi, R.P. and Troye, S.V., 2008. Trying to Prosume: Toward a Theory of Consumers as Co-creators of Value. Journal of the Academy of Marketing Science, 36(1), pp.109-122.

\section{Websites:}

xlviii. CompaniesandMarkets.com, Indonesia Hair Care Market: New market research published: Hair Care in Indonesia, 29 December 2014, viewed 14 February 2017, https://search.proquest.com/docview/1640780518?accountid=13771

xlix. Hanslip, S., Mass Market Retailers, New York, 2017,A look at hair care margin, viewed 1 June 2017, http://digitaledition.massmarketretailers.com/jano92017/Default/48/o

1. Website of Ministry of Industry Republic of Indonesia 2013, Indonesia lahan subur industri kosmetik, viewed 19 February 2017, http://kemenperin.go.id/artikel/5897/Indonesia-Lahan-Subur-Industri-Kosmetik

\section{Newspaper:}

li. Ottoman, J 1998, 'Innovative marketers give new products the green light', Marketing News, 30 March 1998, viewed 24 February 2017, file://C:/Users/Intel/Downloads/out\%20(8).pdf 